\title{
STUDY OF WATER CONSERVATION MEASURES APPLICABLE FOR JAIPUR
}

\author{
Manish Kumar ${ }^{1}$, Niteesh Agrawal ${ }^{2}$, Nitin Kumar ${ }^{3}$, Ramesh Kumar Bagariya ${ }^{4}$, Rohit Goyal $^{5}$ \\ ${ }^{I}$ B.Tech Student, Malaviya National Institute of Technology, Rajasthan, India \\ ${ }^{2}$ B.Tech Student, Malaviya National Institute of Technology, Rajasthan, India \\ ${ }^{3}$ B.Tech Student, Malaviya National Institute of Technology, Rajasthan, India \\ ${ }^{4}$ B.Tech Student, Malaviya National Institute of Technology, Rajasthan, India \\ ${ }^{5}$ Professor, Malaviya National Institute of Technology, Rajasthan, India
}

\begin{abstract}
In the modern era, water scarcity is a prime concern for the proper growth and development of human settlements. Jaipur, being the capital city of Rajasthan, holds a large number of population which suffers from water crisis on a daily basis. Water supply from Bisalpur dam on Banas River is not enough to facilitate water demand of Jaipur. Presently, there is a shortage of 60 MLD of water in Jaipur. In coming years, the population is going to increase, but the water resources are limited. Therefore, increasing water use efficiency is very critical for sustainable water supply. This study focuses on the household survey of water use pattern in different localities of Jaipur. The scope of various water conservation techniques like dual flush toilets, low-flow faucets, bucket bathing, etc. has been analyzed to fulfill current water deficit. It was concluded that promotion of above-mentioned conservation techniques in $60 \%$ households of Jaipur can adequately cover the present water deficit. Encouraging water conservation measures among residents of Jaipur can also help in overcoming water deficiency in future due to demand escalation.
\end{abstract}

Keywords: Water Scarcity, Water Conservation Methods, Future Forecast, Household Survey

\section{INTRODUCTION}

Water is a very essential element in human life. It is required for almost every work. Rapid increment in the standard of living, urbanization and industrialization has increased the water requirement many folds. Due to improper management and scarcity of water resources, $11 \%$ of the global population do not have access to drinking water source [1]. As the global population is increasing exponentially, the time is near when wars will be fought over water. To avoid this kind of situation, proper steps for water conservation must be taken now.

\section{LITERATURE REVIEW}

Water is a key resource, necessary for all living organisms such as humans, animals and plants. As availability of water is limited for any area, it is essential to manage the water resources optimally for the well being of any area [2].

Presently 24 hours of municipal water supply is available to only $18 \%$ of the households in the major cities of India. Condition of municipal water supply in other cities is worse. As a result majority of the households depend on groundwater either from their own resources or through private vendors who supply water through tankers. This, in turn, has resulted in rapid depletion of groundwater in some area [3].

Efficient use of municipal water holds many advantages for a community. High rate of freshwater withdrawals can cause deterioration of environment and social problems in the long-run. As a consequence of overwithdrawal, availability of safe potable water reduces for the future generations [4]. Therefore, focus must be shifted to demand-side aspects like enhancing water use efficiency and promotion of water conservation technologies [5].

Techniques such as rainwater harvesting could additionally be used to increase supply at desired locations. Goyal (2014) discussed some of the issues and challenges in rooftop rainwater harvesting [6].

\section{STUDY AREA}

Jaipur, the capital of Rajasthan State, is situated in the eastern part having the lattitude of $26.9^{\circ} \mathrm{N}$ and longitude $75.8^{\circ} \mathrm{E}$ with an average altitude of approximately 431 metre. The total population of the city has reached 3.1 million in the year 2011, making it to the list of top ten most populated cities in India [7]. Jaipur, popularly known as Pink City, is one of the most popular tourist destination in India.

Climate of Jaipur is hot and semi-arid. It receives about 650 $\mathrm{mm}$ (26 inches) of rainfall annually. Majority of the rain occurs in the monsoon months of June and September. Temperature of Jaipur remains relatively high all round the year. Average daily temperature during summer months of April to early July hovers around $30{ }^{\circ} \mathrm{C}$. Rains and thunderstorms are frequent during monsoons, but the flood is not so common. During winter season, average temperatures ranges from $15-18{ }^{\circ} \mathrm{C}$ and with very little humidity [8]. 
Jaipur receives most of its domestic water through the Bisalpur Dam in Tonk district. Daily 600 MLD of water is required for domestic use, of which 540 MLD is supplied through the Dam. Currently, Jaipur is facing a shortage of 60 MLD of water [9]. In this study, the emphasis is on fulfilling this water shortage by three main conservation techniques- dual flush toilets, low-flow faucets and bucket bathing. A survey questionnaire was framed to determine current water use pattern in households of Jaipur and their attitude towards water conservation measures.

A total of 192 houses were surveyed with participation from all income groups- low, middle and high income groups.

Household survey has been done in the main residential areas of Jaipur like Mansarovar, Jawahar Nagar, Jagatpura, Badi Chaupad, Malviya Nagar, Chitrakoot, Civil Lines, Vidyadhar Nagar, etc. All survey locations have been shown in the map of Jaipur below (Fig- 1).

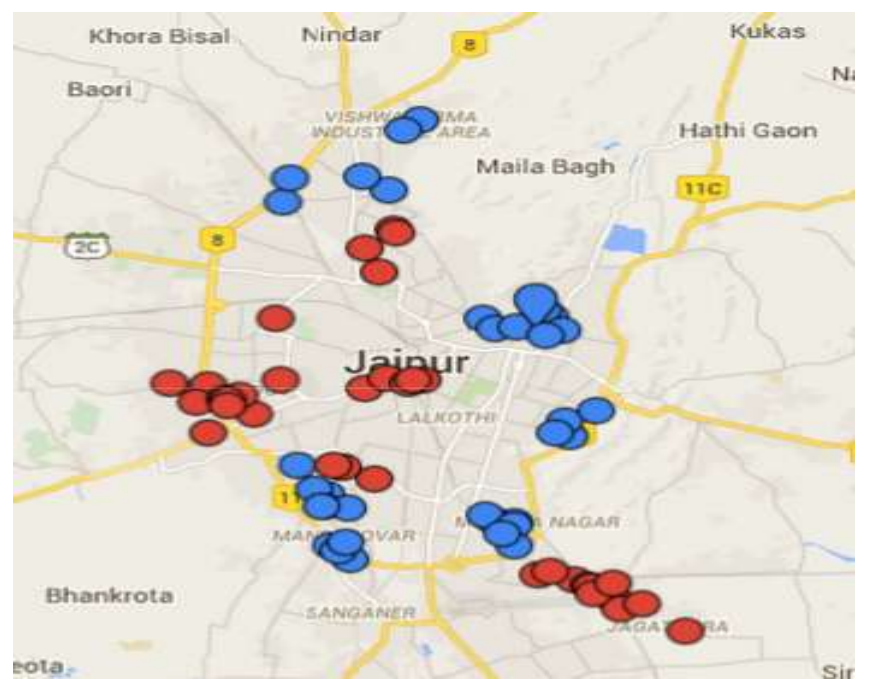

Fig -1: Survey locations in Jaipur

\section{SURVEY METHODOLOGY \\ OBSERVATIONS}

AND

During the field survey in Jaipur, many questions were asked about the water use pattern and the likelihood of adopting water conservation measures. Some sample survey questions are shown in Table 1 below:

Table -1: Sample Survey Questions

\begin{tabular}{|l|}
\hline Roof Material: \\
\hline $\begin{array}{l}\text { Windows (Circle one): No windows Windows(no glass) } \\
\text { Glass windows }\end{array}$ \\
\hline Has Electricity (Circle one): \\
\hline Number of bedrooms: \\
\hline Own home: Yes Norated glass windows
\end{tabular}

\subsection{Income Group Calculation}

Income group of survey participants has not been asked directly, rather certain factors have been fixed to know their financial status. All factors have been compiled in Table-2. According to survey participants response, the value of the various factors was awarded.

Thereafter, Income group was decided on the basis of the sum of factors. If sum was 4-5, then High Income Group (HIG), if the sum was 1-3, then Middle Income Group (MIG) and if the sum was $<=0$, then Low Income Group (LIG).

Table -2: Factors to find Income Group

\begin{tabular}{|l|c|}
\hline Participant's response & Factor' value \\
\hline Roof material: & -1 \\
Tin; plastic; grass; mud & 1 \\
Concrete; slate; tile; stone & \\
\hline Electricity: & 0 \\
Electricity & -1 \\
No electricity & \\
\hline Windows: & -1 \\
No windows; windows without & \\
glass & 0 \\
Plain glass windows & 1 \\
Decorated glass windows & \\
\hline Number of Vehicles: & -1 \\
None; only bicycles & 0 \\
$<3$ two wheelers, no car & 1 \\
1 car & 2 \\
$>=2$ cars & -1 \\
\hline House Ownership: & 0 \\
Rents home & -1 \\
Owns home & 0 \\
\hline Bedroom/Person Ratio $(\mathbf{x})$ & \\
$<0.25$ & \\
$0.25<=x<0.5$ & \\
$>0.5$ & \\
\hline Sum of factors & \\
\hline & \\
\hline
\end{tabular}

\subsection{Quantitative Distribution of various types of}

\section{Toilets}

Toilets have been divided into three categories as per their flushing system-

- Single flush

- Dual Flush

- Pour Flush

Information about type and number of toilets installed in the households has been collected by door to door survey. Quantitative distribution of toilets in households of Jaipur is given in Table -3 below. 
Table -3: Quantitative distribution of toilets in households of Jaipur

\begin{tabular}{|l|l|l|l|l|l|l|}
\hline $\begin{array}{l}\text { Income } \\
\text { group }\end{array}$ & $\begin{array}{l}\text { Total } \\
\text { no. of } \\
\text { houses }\end{array}$ & $\begin{array}{l}\text { Total } \\
\text { no. of } \\
\text { people }\end{array}$ & $\begin{array}{l}\text { No. of } \\
\text { dual } \\
\text { flush } \\
\text { toilets } \\
\text { installed }\end{array}$ & $\begin{array}{l}\text { No of } \\
\text { pour } \\
\text { flush } \\
\text { toilets }\end{array}$ & $\begin{array}{l}\text { no. of } \\
\text { single } \\
\text { flush } \\
\text { toilets }\end{array}$ & $\begin{array}{l}\text { Total } \\
\text { no of } \\
\text { toilets }\end{array}$ \\
\hline HIG & 51 & 328 & 54 & 4 & 115 & 173 \\
\hline MIG & 117 & 654 & 66 & 16 & 197 & 279 \\
\hline LIG & 24 & 152 & 12 & 6 & 30 & 48 \\
\hline Total & 192 & 1134 & 132 & 26 & 342 & 500 \\
\hline
\end{tabular}

\subsection{Likelihood of Installing Dual Flush Toilets}

To find the likelihood of installing dual flush toilets, survey participants were asked to give their opinion on a scale of 1 to 5 , where 1 means not at all likely to install dual flush toilets and 5 means extremely likely to install dual flush toilets. They were asked to give the rating by considering all relevant factors like money involved, attitude of family members etc. Likelihood of installing dual flush toilets in households of Jaipur has been graphically represented in Chart -1 .

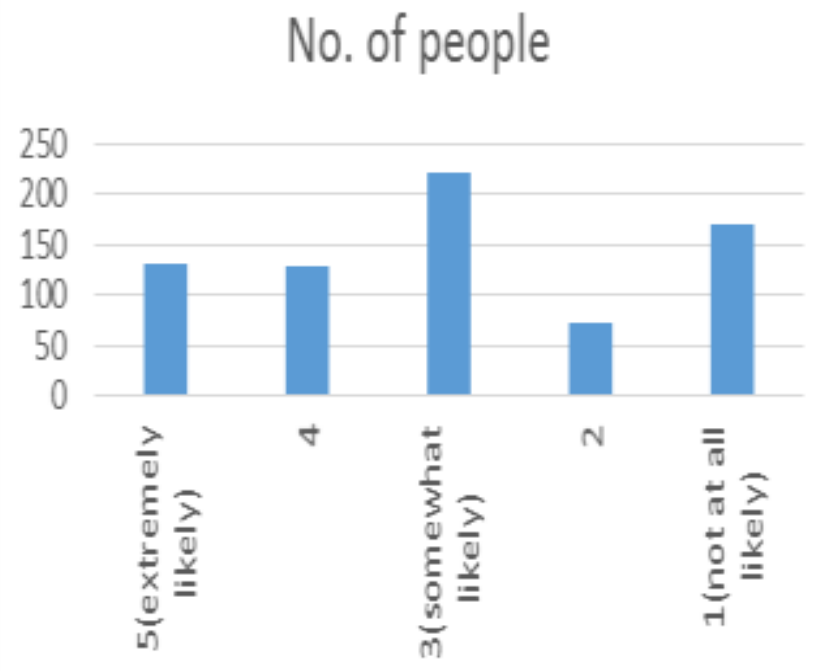

Chart -1: Likelihood of installing dual flush toilet (DFT)

Note-

1. Likelihood of installing low flow faucets has been taken same as the likelihood of installing of dual flush toilets.

2. Number of low flow faucets installed at present has been taken same as of number of dual flush toilets.

\subsection{Quantitative Distribution of Bathing Preference}

In Jaipur, there are only two major modes of bathing- bucket and shower. Some persons use both systems as per their mood. Bathing preference of survey participants was asked and presented in Table- 4 below. Since bathing preference is a personal choice, it has not been superimposed over all persons of the household.
Table -4 No. of people using shower and buckets for Bathing

\begin{tabular}{|l|l|l|l|l|}
\hline $\begin{array}{l}\text { Income } \\
\text { group }\end{array}$ & $\begin{array}{l}\text { Total no. } \\
\text { of people }\end{array}$ & $\begin{array}{l}\text { No. of } \\
\text { people } \\
\text { who use } \\
\text { shower }\end{array}$ & $\begin{array}{l}\text { No. of } \\
\text { people } \\
\text { who use } \\
\text { buckets }\end{array}$ & $\begin{array}{l}\text { No. of people } \\
\text { who use both } \\
\text { shower \& } \\
\text { bucket }\end{array}$ \\
\hline HIG & 51 & 25 & 0 & 26 \\
\hline MIG & 117 & 80 & 7 & 30 \\
\hline LIG & 24 & 23 & 0 & 1 \\
\hline Total & 192 & 128 & 7 & 57 \\
\hline
\end{tabular}

\section{ANALYSIS OF SURVEY DATA}

\subsection{Analysis of Flushing System}

Water required to flush solid and liquid waste in different types of toilets is shown in Table-5. It has been taken that a person flushes out solid waste 2 times per day and liquid waste 3 times per day [10].

Table -5: Water requirement of different types toilets

\begin{tabular}{|l|l|l|l|l|}
\hline $\begin{array}{l}\text { S. } \\
\text { No. }\end{array}$ & $\begin{array}{l}\text { Type of } \\
\text { toilet }\end{array}$ & $\begin{array}{l}\text { Water } \\
\text { required in } \\
\text { flushing } \\
\text { solid waste } \\
\text { (Litre) }\end{array}$ & $\begin{array}{l}\text { Water } \\
\text { required in } \\
\text { flushing } \\
\text { liquid } \\
\text { waste } \\
\text { (Litre) }\end{array}$ & $\begin{array}{l}\text { Total water } \\
\text { used per } \\
\text { person per } \\
\text { day }\end{array}$ \\
\hline 1. & $\begin{array}{l}\text { Single } \\
\text { Flush }\end{array}$ & 10 & 10 & $\begin{array}{l}10 \times 2+10 \times 3= \\
50\end{array}$ \\
\hline 2. & $\begin{array}{l}\text { Dual } \\
\text { Flush }\end{array}$ & 6 & 3 & $6 \times 2+3 \times 3=21$ \\
\hline 3. & $\begin{array}{l}\text { Pour } \\
\text { Flush }\end{array}$ & 6 & 3 & $6 \times 2+3 \times 3=21$ \\
\hline
\end{tabular}

It is quite clear that dual flush and pour flush toilets are much more water efficient than single flush toilets. Single flush toilets require more than double amount of water than the other two. So from water efficiency perspective, dual flush and pour flush toilets should be preferred. However pour flush toilets are not recommended due to sanitation problems. Dual flush toilets are quite convenient to use and maintain hygienic conditions in the washrooms. Therefore, dual flush toilets must be supported to tackle water unavailability problem.

Water use per person per day for flushing purpose has been calculated. Results have been compiled according to income group of households in Table- 6 .

Table -6: Current water use in flushing

\begin{tabular}{|l|l|l|}
\hline $\begin{array}{l}\text { S. } \\
\text { No. }\end{array}$ & Income Group & $\begin{array}{l}\text { Water use in flushing per } \\
\text { person per day (LPCD) }\end{array}$ \\
\hline 1. & HIG & 40.74 \\
\hline 2. & MIG & 41.76 \\
\hline 3. & LIG & 40.94 \\
\hline 4. & Total & 41.36 \\
\hline
\end{tabular}


Data from table 6 indicates that there is lot of water conservation potential in Jaipur, only by replacing conventional toilets with dual flush toilets. Dual flush toilets require 21 litre of water for flushing per person per day; which is 20.36 litre less than the current water use in Jaipur for flushing.

If $60 \%$ residential toilets in Jaipur be replaced by dual flush toilets, about $\mathbf{4 3 . 3}$ million litre of water can be saved per day.

\subsection{Analysis of Bathing System}

Water requirement for bathing via bucket has been assumed as 40 litre per person per day. Water requirement for bathing via shower has been taken as 65 litre per person per day [11]. In shower bath, water wastage is more because the shower is let open for most of the bathing time; which is not required. It has been assumed that everyone baths once per day. Water requirement for bathing has been calculated for Jaipur as per survey data. It is 44.85 litre per person per day. Most of the survey participants prefer bucket bath over shower.

Table -7: Current water use in bathing

\begin{tabular}{|l|l|l|}
\hline S. no. & Income Group & Water use in bathing (LPCD) \\
\hline 1. & HIG & 46.37 \\
\hline 2. & MIG & 44.70 \\
\hline 3. & LIG & 40.52 \\
\hline 4. & Total & 44.62 \\
\hline
\end{tabular}

As bath via bucket is more water efficient, it should be promoted to save water.

If only $60 \%$ citizens of Jaipur are encouraged to bath via bucket, 10 MLD water can be saved.

\subsection{Analysis of Faucets and Taps}

Water use through faucets in residential houses is about $15 \%$ of total water use [12]. Low flow faucets save around 50\% water as compared to conventional one [13]. It has been assumed that low flow faucets are installed in those houses which have already installed dual flush toilets. The assumption is quite appropriate as both are latest technologies and the possibility of installing one and neglecting other is negligible.

Total water use in households of Jaipur has been taken from 'Water consumption pattern of Jaipur city by Jethoo and Poonia' [14].

Current water use through faucets in households has been calculated and summarized in Table 8.
Table -8: Current water use through faucets

\begin{tabular}{|l|l|l|l|l|}
\hline $\begin{array}{l}\text { S. } \\
\text { No. }\end{array}$ & $\begin{array}{l}\text { Income } \\
\text { group }\end{array}$ & $\begin{array}{l}\text { Total water } \\
\text { use per } \\
\text { person per } \\
\text { day } \\
\text { (LPCD) }\end{array}$ & $\begin{array}{l}\text { Water use } \\
\text { through } \\
\text { faucets per } \\
\text { person per } \\
\text { day (LPCD) }\end{array}$ & $\begin{array}{l}\text { Water } \\
\text { requirement } \\
\text { if only low } \\
\text { flow faucets } \\
\text { are used } \\
\text { (LPCD) }\end{array}$ \\
\hline 1. & HIG & 139.3 & 16.31 & 10.45 \\
\hline 2. & MIG & 130.9 & 16.83 & 9.82 \\
\hline 3. & LIG & 114.1 & 15.26 & 8.56 \\
\hline 4. & Total & 128.8 & 16.47 & 9.66 \\
\hline
\end{tabular}

If $60 \%$ faucets in houses of Jaipur are converted into low flow faucets, 12.89 million litre of water can be saved daily.

From all three conservation measures, a total of 66.19 MLD of water can be saved. Current water supply deficit in Jaipur is $60 \mathrm{MLD}$; which can easily be fulfilled by adopting above mentioned strategy.

\section{FUTURE FORECAST}

Considering the present scenario of water shortage in Jaipur, the future condition is going to be worse. It has become the need of the hour to increase water resources or to conserve more water.

According to an estimate, the population of Jaipur in 2025 is going to be 64.95 lakhs [15]. Keeping the water demand same as it is today i.e. $125 \mathrm{~L}$ of water per person per day, total water demand of Jaipur will be 812 MLD [9].

Presently 540 MLD of water is being supplied to Jaipur through Bisalpur Dam, so there will be a shortage of 272 MLD. If Jaipur starts using dual flush toilets, bathing via buckets and low flow faucets from today itself; then it can be easily supposed that $90 \%$ population would be using the same by 2025 . Then approximately 181 MLD of water can be conserved. After that, there will be a shortage of only 91 MLD of water.

This remaining water shortage can be fulfilled by:

- Dual plumbing

- Rain water harvesting

- Watering at proper and particular time of day to reduces evaporation losses.

\section{CONCLUSION}

By this study, following important conclusions can be drawn:

- Present water supply shortage of 60 MLD in Jaipur can be effectively overcome by reducing water consumption via various water conservation techniques.

- Replacing $60 \%$ toilets by dual flush toilets can reduce water demand of Jaipur by 43.3 MLD.

- Installation of $60 \%$ low flow faucets can save 14.4 MLD of water. 
- Encouraging citizens of Jaipur to bath by bucket will conserve 10 MLD of water.

- Water deficiency in future can be regulated by encouraging water conservation measures.

Promotion of dual flush toilets, bathing by buckets (no shower heads) and low flow faucets can be achieved by following measures:

- Providing subsidy on dual flush toilets and low-flow faucets instead of spending on the introduction of water resources.

- Levying additional taxes on shower heads and bath tubs.

- $\quad$ Running awareness programs and introducing benefits of installing dual flush toilets and low-flow faucets to common people.

\section{REFERENCES}

[1]. UNICEF/WHO, (Accessed on April 2016), "Millennium Development Goal drinking water target met", URL:

Www.who.int/mediacentre/news/releases/2012/drinking_wat er_20120306/en/

[2]. Jethoo A.S. and Poonia M.P., (2011), "Sustainable Water Supply Policy for Jaipur City", International Journal of Environmental Sciences, Vol. 1(6)

[3]. Shaban A. and Sharma R. N., (2007), "Water Consumption Patterns in Domestic Households in Major Cities", Economic and Political Weekly, Vol. 42, No.23, June 9, 2007, pp.2190-2198

[4]. Hota S., (2014), "Utilization and Consumption Pattern of Water in Urban Areas: A Study in Sambalpur City of Odisha", Department of Humanities and Social Sciences, National Institute of Technology, Rourkela

[5]. Reddy V.R., (2003), "Costs of Resource Degradation Externalities: A Study of Groundwater Depletion in Andhra Pradesh", Centre For Economic and Social Studies

[6] Goyal R., (2014), "Rooftop Rainwater Harvesting: Issues \& Challenges", India Plumbing today, 125 Collector's Edition: 148-161

[7]. Roberts K., Reiner M., and Gray K., "Water Scarcity in Jaipur, Rajasthan, India", PDF file by Northwestern University

[8]. Dass A., Jethoo A.S. and Poonia M.P., (2012), "Impact of Drought on Urban Water Supply: A Case Study of Jaipur City", International Journal of Engineering and Innovative Technology, Vol. 1(3)

[9]. Jain S., (2016), "Drinking water management of Jaipur city", Powerpoint presentation by PHED office

[10]. Mathur S., (2016), "Water Efficiency", Powerpoint presentation by Rajasthan State Pollution Control Board Dept.

[11]. Alliance for Water Efficiency, (Accessed on May 2016), "Residential Shower and Bath Introduction", URL: "http://www.allianceforwaterefficiency.org/Residential_Sho wer_Introduction.aspx"

[12]. United States Environmental Protection Agency, (Accessed on May 2016), "Bathroom Faucet Fact sheet", URL:

"https://www3.epa.gov/watersense/pubs/ws_bathroom_fauc ets.html"
[13]. Speer A., (Accessed on May 2016) "Water Conservation", URL:

"http://www.isustainableearth.com/waterconservation/money-saving-water-conservation-tips" [14]. Jethoo A.S. and Poonia M.P., (2011), "Water Consumption Pattern of Jaipur City (India)", International Journal of Environmental Science and Development, Vol. 2(2)

[15]. Jaipur Development Authority, (Accessed on May 2016) "Development Plan-2025", Jaipur region" URL: "https://www.jaipurjda.org/pdf/MDP/Vol2.pdf" 